\title{
A Radical - Transformational Change Through Leadership
}

\author{
HARTINI AHMAD \\ Faculty of Business Management \\ Universiti Utara Malaysia. \\ ARTHUR FRANCIS \\ School of Management, \\ University of Bradford.
}

This paper is concerned with leadership practices in a radical process change, namely, business process reengineering (BPR). The paper looks at the higher education context, which has successfully Dimplemented BPR in their key processes. The results were taken from three in-depth case studies using the triangulation approach which includes open-ended interviews and use of secondary data. The results had shown six important leadership factors as key drivers to enable process change to happen successfully. Leaders need to be able to practise different leadership approaches or styles based on situations, emphasise on a strategic vision, use effective communications, do reinforcement, give commitment and support, and have leadership qualities. Some suggestions regarding leadership best practices for a radical transformational change are also outlined.

-
ABSTRAK

C.

Artikel ini menekankan tentang amalan kepimpinan di dalam perubahan proses yang radikal, iaitu proses perekasayaan semula. Artikel ini menjurus kepada konteks pendidikan tinggi. Dapatan diperoleh daripada tiga kajian kes yang dilakukan secara mendalam menggunakan pendekatan triangulasi merangkumi temu bual terbuka dan data sekunder. Hasil kajian menunjukkan enam faktor kepimpinan yang terpenting sebagai penggerak utama bagi memastikan perubahan proses berjaya dilaksanakan.

- Pemimpin perlu mengamalkan kepelbagaian dalam pendekatan atau gaya kepimpinannya, iaitu berdasarkan kepada situasi yang dihadapinya. Selain itu, pemimpin perlu menekankan visi yang strategik, menggunakan komunikasi yang efektif, memberi dorongan, komitmen dan sokongan, serta mempunyai kualiti kepimpinan tertentu. Beberapa cadangan berkaitan dengan amalan terbaik kepimpinan untuk perubahan radikal telah digariskan.

\section{INTRODUCTION}

The environment is rapidly changing. Therefore, organisations need to adapt constantly to these changes. In doing so, the management needs to be well prepared and ready for any risks that may occur from transformational efforts that take the organisation outside the current rules of the game and the people outside their comfort zones Dale, (1994). Ascari, Rock and Dutta (1995) recognised that a constant challenge faced by today's management is change, and change itself is changing also (Hayes, 2000). Huber and Glick (1995) posited that organisational changes are a 
departure from the status quo. The authors highlighted two forces for change: firstly, the organisation's top managers, and secondly, the firm's environment.

\section{LITERATURE REVIEW}

\section{Organisational Change and Transformation}

The change in the organisation itself will face difficulties in its implementation because of the resistance to change from employees, particularly large-scale organisational changes (Applebaum \& -Wohl, 2000; Markus \& Benjamin, 1997). Therefore, there is the need for the top management to handle and motivate the members of the organisation to accept and apply changes (Altman \& Iles, 1998; Hammer \& Stanton, 1995; Harrington, 1991; Hayes, 2000; Zairi, 1999). A - number of authors draw a distinction between the concept of management and leadership in the change issue. Applebaum and Wohl (2000) and Kotter (1995) commented that the management is concerned with the maintenance of the status quo, while leadership is more concerned with change. Kotter (1995) further stated that the - management is involved in maintaining order and Consistency of an organisation, and engaged in planning and budgeting; whereas leadership is involved in setting a direction, developing a vision of the future, and formulating strategies for achieving the vision. An organisation needs to avoid any critical mistakes in any of the change processes, if not, it would be harmful to the - organisation.

A large-scale organisational change becomes a transformation when it is radical and drastic in its implementation, in which the business itself may be reinvented (Applebaum \& Wohl, 2000; Edwards, Braganza, \& Lambert, 2000; Kotnour, 2001; MacIntosh \& MacLean, 1999). Further elaboration is on the factors associated with organisational transformation, that is environmental characteristics consisting of turbulence, competitiveness, and complexity. Higher education institutions (HEIs) in Malaysia are typical examples of the more general phenomenon of organisations operating in rapidly changing environments. This implies the need for rapid and perhaps radical organisational changes. Such changes have been the subject of study by many researchers and several different approaches have been adopted such as continuous improvement, total quality management (TQM), and BPR (Applebaum \& Wohl, 2000; Benito, Martinez-Lorente, \& Dale, 1999)

Various types of transformation are also discussed by many authors (Davenport, 1993a; Hayes, 2000) who listed several forms of transformations, including reengineering, downsizing, building a virtual organisation, launching total quality management, or redefining core competencies to build competitive advantages. Reengineering is a transformational change, which has different distinguishing attributes in terms of the degree of transformation, the scope of operations, the potential benefits and risks, the type of effort whether continuous or discontinuous, and obviously, its radical nature.

\section{Transformational Leadership}

The issue of leadership is thought to be a key ingredient for radical process change success. stated that a successful change leader has a realistic and positive expectation about the outcome. The larger and more diverse an entity, the more difficult it is to affect and manage change. BPR efforts require higher coordination and cooperation across both internal and external interfaces, which place unprecedented demands on the change management, and require, in addition to time and money, skill, determination, persistence, and patience on the part of the leaders and managers involved in the change. Smith (2003) highlighted that BPR aims to achieve performance breakthrough by applying innovative ways of doing business. A few things that are needed to manage radical change effectively include effective leadership to coordinate deployment of the resources to accomplish the strategic objectives and communication to show support for the BPR project.

More recently a number of researchers have identified the key role of leadership in organisational transformation which is embedded in a learning environment. For example, Applebaum and Wohl (2000) agreed that the leader establishes a learning environment so that it would 
enable the organisation to move ahead. Zairi (1999) identified one important factor for creating effective change in the context of the learning organisation (LO) as being leadership, with the leader principles, including the need for a clear vision, leadership and communication, and an effective decision-making process at all levels, driven by business imperatives.

In order to enable the LO to undertake -organisational transformation, the importance of the leader is recognised in mastering not only the technical part but also the psychological part. emphasised that failure in the role of the leader of

the organisation has led to problems in transformation. They identified leadership as a key role in directing, channelling, and focusing such learning. Additionally, they highlighted that the Crole model leadership should include trust and openness, support systems, training and development, open communication systems and empowerment. Laiken (2003) pointed out that a strong leadership could develop and motivate work groups to increasingly become selfmanaging, and therefore the groups could take responsibility for autonomous and effective decisions.

In conclusion, there appears to be a consensus that leadership is considered a vital role in managing change and guiding BPR towards success. Thus, there is a view that there is a need for a more practical framework to guide leaders through the transformational change effort.

\section{RESEARCH METHODS}

\section{Case Study Approach}

Existing literature (Altman \& Iles, 1998; Francis \& MacIntosh, 1997; Halachmi, 1995; Hall, Rosenthal, \& Wode, 1993; Homa, 1995) suggests that the assessment of BPR in organisations, also in HEIs, would benefit more by investigating indepth the real experience of implemented BPR. Therefore, we identified established PHEIs which had embarked on BPR for a detailed case study approach. The selection of the case study PHEIs were based on some decisive factors, a) implementation of BPR/ nature of 'radicalness' in process change implementation, and b) successful BPR project over the last 5 years. Therefore, we have chosen Case 1: HEI-A, Case 2: HEI-B, and Case 3: HEI-C.

Actual case study fieldwork was done through a triangulation approach to get both breadth and depth information, which is in line with suggestions in Miles and Huberman (1994) and Yin (1994), with an open-ended interview involving the top management (for example, chief executive officers, directors, deans, and managers). They were asked to identify the leadership factors, particularly from the strategic BPR practices, in terms of mission and vision, and also other elements such as commitment, support, and communication (Altman \& Iles, 1998; Berrington \& Oblich, 1995; Davenport, 1993a; Kock \& MCQueen, 1996; Kotter, 1995).

\section{Open-Ended Interviews}

Specifically, this study had developed a set of interview questions on the leadership factors, which were put to the top management and BPR team of the case organisations. Some questions include: "Could you please explain the leadership and management practices in the BPR which happened in your organisation?" and "How do you prepare your employees for BPR or radical process change?". The instruments for open-ended interviews were developed based on the literature review, most of them being adapted from AlMashari \& Zairi, (1999) and Guimaraes (1999). In addition, the instruments also included several points regarding the different context and different country, which stressed the cultural background (Peppard \& Fitzgerald, 1997).

\section{DATA ANALYSIS}

A cross-analysis focussing on the similarities and differences of all the leadership factors obtained through the analysis was caried out. Additionally, the results from the three case studies were compared with a best practice example or benchmark. The benchmark was taken from University of Wisconsin-Stout (UW-Stout), the winner of the Malcolm Baldrige National Quality Award (MBNQA) in the education category for 
the Year 2001. This is thought to be appropriate because MBNQA is the standard for performance excellence. In fact, MBNQA was envisioned as a standard of excellence that would help organisations to achieve world-class quality. The main software for the data analysis was the Decision Explorer, since this research is focused on the case study which relies much on the qualitative approach, and a linkage diagram of participants' ideas using the Decision Explorer software was developed, based on suggestions by
Ahmad (2003) and Ahmad and Spicer (2002). From the analysis of findings, it was found that many interesting issues resulted from the factors highlighted by the cases. Although the factors derived from the interview sessions vary in terms of numbers and terms used, the coverage of all factors seemed very similar across all three cases. These leadership factors include leadership approach/style, strategic vision, effective communication, reinforcement, commitment and support, and leadership qualities (Figure 1).

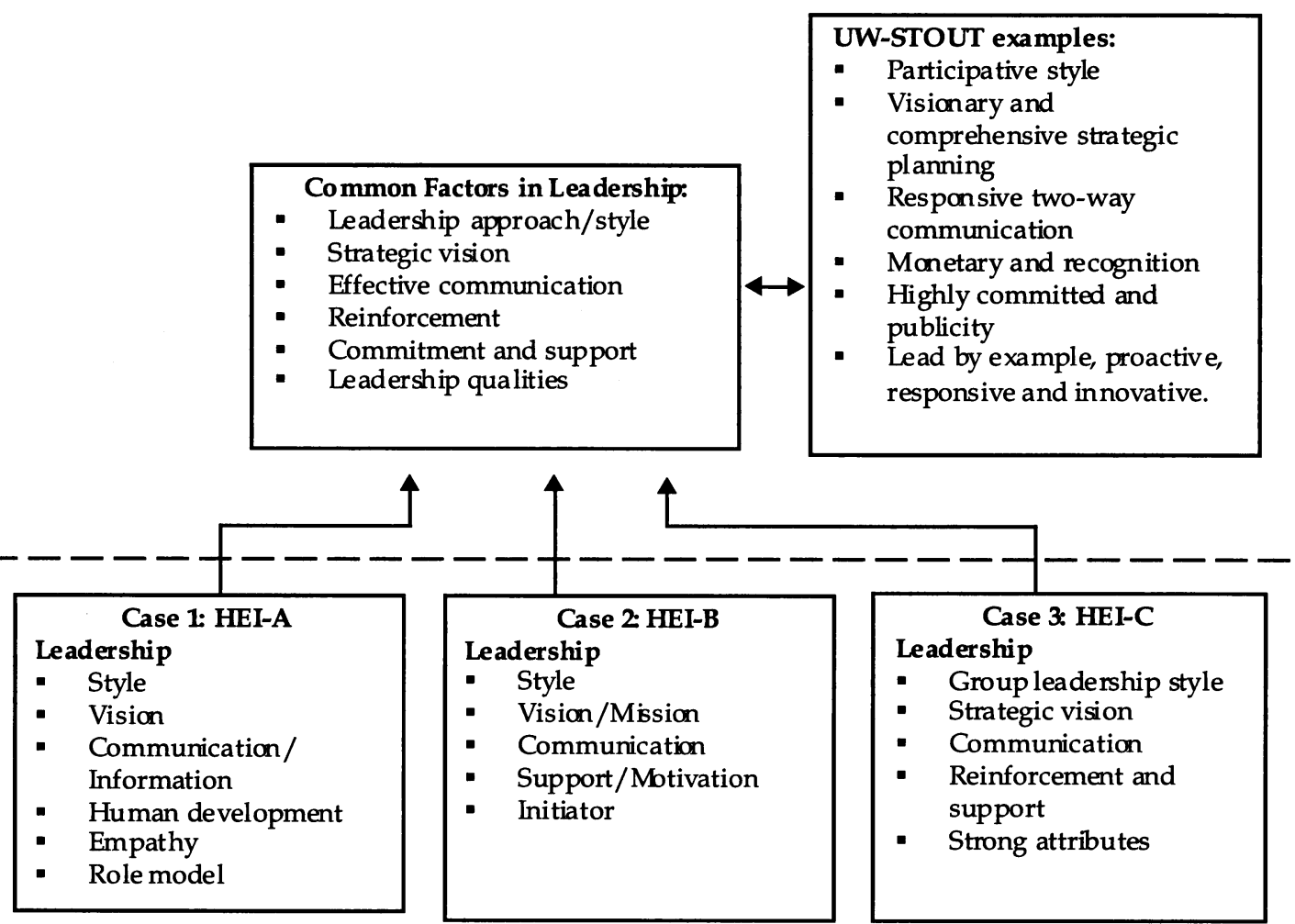

\section{Figure 1}

Cross-comparisons of leadership factors for the case studies

\section{FINDINGS AND DISCUSSION}

It was found that there were common leadership factors across PHEIs which are believed to be important for the success of BPR. Some minor differences were found, only because of their ranked importance, and some were discussed under other sub-factors and fell under different terminology. A re-arrangement and reconstruction of the ideas within one terminology that was perceived more accurate was performed and also validated with the top management of those case 


\section{Leadership Approach and Style}

The first priority in the leadership factor is leadership approach or style. All cases stressed the exis tence of various styles of leadership that are appropriate for certain situations. Leadership style is important in any change efforts and varies, based on different situations (Grieves, 2000) and that a more autocratic style is important to make a quick-fix change (Moran \& Brightman, 2000).

It was observed that leadership approach and style did vary among the case studies. For example, in HEI-A, the emphasis was more on participative style, which was contrary to HEI-B, where the

- approach and style were perceived as more autocratic in nature. HEI-C exhibited both participative and to some extent autocratic approaches.

This paper agrees with previous studies
(Campbell \& Kleiner, 2001; Crant \& Bateman, - 2000; Moran \& Brightman, 2000) that posited a leader should be able to vary the decision-making style according to the situation. This is true, and all three cases were similar in that they believed that in some situations the leader had to make a decision to be more autocratic or participative. However, in terms of to what extent any single or - both styles should be stressed more, all of the case PHEIs agreed that to make a drastic or radical change become possible, the leader should stress more on the autocratic style rather than participative.

In UW-Stout, the practice was mostly a participative style. Each department had to contribute ideas for process improvement, which - was done during regular meetings. One example was to flatten the organisational structure through broad involvement of all governance bodies. Furthermore, there was a participatory decisionmaking to achieve consensus, and enhanced opportunity for meaningful faculty and staff roles in shared governance matters.

This paper advocates that most successful leaders use a variety of approaches, incorporating both autoctatic and participative styles, where one type should have dominance in particular situations. This suggests that the leader should be autocratic to ensure things are done as scheduled, particularly in the technical parts of the process change such as the accomplishment of activities, i.e. the importance of the leader being more autocratic in order to attain faster solutions to problems (Moran \& Brightman, 2000) On the other hand, in a critical perspective writing, McAdam (2003) considered the involvement of employees at a fundamental level as crucial to the success of radical or large-scale change. This is in line with UW-Stout, which implemented participatory decision-making to achieve consensus and empowerment was given to departments to operate within their budget allocation or to request additional resources or the reallocation of funds (UW-Stout, 2003). Leaders who can develop a good relationship with employees will foster a positive influence and continuously monitor their needs and satisfaction.

\section{Strategic Vision}

Strategic vision is an important element in process change and could improve the business performance at a desirable level (Al-Mudimigh, Zairi, \& Al-Mashari, 2001; Ascari et al., Tinnila, 1995), however, without proper action to achieve this, it would be meaningless (McAdam, 2003). Furthermore, this author stated that the vision for an organisation acts as a pull factor for radical change. Through the data analysis, it was found that all three cases have reinforced this particular view, for example, both HEI-A and HEI-B reevaluated their strategic directions and visions annually. Obviously, the leader in HEI-C believed that a clearly spelled out vision would inspire change and make a right move for the organisation to achieve its target. This statement is in line with Mumford (1999) and Zairi (1999), whom stated that a clear and concise vision was important for an organisation to achieve its change goals.

It was found that these PHEIs have examined how strategies and process change complement each other. This is in line with UWStout, which implemented a comprehensive annual strategic planning processes that aligns campus priorities with the allocation of resources. The evidence seems to suggest that in strategic vision, the organisation has to link with businesses processes and bear the customer in mind as a means for the effectiveness of process change. In UW-Stout, through the Stout Student Association (SSA), they had obtained student academic and 
service needs from representation on the Strategic Planning Committee and Chancellor's Advisory Council (UW-Stout, 2003). This benchmark university has strategic planning with a strong connection to the annual budget process, and at the same time it is highly focused on its customers by being effectively responsive to their needs.

Furthermore, strategic vision is important to guide process change to be implemented successfully, and this is translated into strategic and tactical actions. Mabin, Forgeson and Green (2001) declared that vision relates to a picture of a future shape of an organisation and the needed commitment from the leadership. For example, the development of UW-Stout's vision and values was based on their collaborative efforts

of participative management, which resulted in a realistic and understandable vision (UW-Stout, 2003). This university had identified gaps between its own current performances and those of other universities or best practices, and it had also wished to align resources to its strategic plans. Therefore, this paper suggests that in order to face strategic challenges, process change in PHEIs should be guided by its strategic vision, and it is becoming a focal point for the PHEIs to increase their process performance to ensure customer satisfaction and, in the end, this would improve the business performance significantly, which is parallel to Burlton's (2001) views.

\section{Effective Communication}

All three cases perceived that using various media and methods of communication enabled leaders to communicate their plans and expectations more learly. In a particular case, HEI-A used communication channels such as the intranet and memos to increase the communication rate. Screen savers were used on every individual computer for displaying the Chief Executive Officer (CEO) messages and desires. In addition, regular informal interaction was stressed in order for the leaders to motivate people to support changes. HEI-C also practised communication on a regular basis by providing important messages using the website and displaying them on a noticeboard for every division. It was believed that by using these methods, this would increase awareness among employees and also serve as reminders to leaders.
It should be noted that inspiration and motivation from the leader was done quite informally by following the slogan of "talk and listen to people with compassion", reflecting a psychological perspective which believes that this will make the message more absorbable cognitively by people. This belief of the HEI-C leader was parallel to a study done by LaMarsh (1997) and Zaugg and Thom (2003), who observed that people's resistance to change can be made manageable and avoidable by personal attention, which makes them willing to support such change actively, and they would make a lot of improvements. HEI-B used communication in a more directive manner, most frequent through meetings and by using formal letters and circulations to the organisation, for example, formal letters to all Heads of Schools to ask for participation and contribution in the knowledge management $(\mathrm{KM})$ programme.

Beside the media for communication, how leaders communicate with others was important, since all three case PHEIs believed that transparency in communication was important to ensure people grasp clearly what they are supposed to give, and know exactly the boundaries in their organisation. It should be noted that transparency is important to manage people to commit themselves to making changes happen successfully. This issue was discussed in past research:

The inability of an organisation to determine and communicate its view of processes or the way it intends to use that perspective can create a level of cynicism among its members which may be difficult to overcome by the time they are asked to implement that strategy. While this clarity of vision and intent from the top may be an obvious component of any strategy development...

(Pritchard \& Armistead, 1999:19)

The evidence suggests leadership should impose the principle of being transparent and practise highly effective communication to make the goals and targets clear for employees at all levels to achieve. The use of various methods of communication, manual or computerised, formal or informal, personal or impersonal are important to make the message rapidly reach employees, so 
that they will be more aware and understanding. This is parallel to UW-Stout, where the leaders encourage responsive two-way communication, have strong communication linkages, and interestingly, practise more cross-organisation communication in order to accomplish its mission, values, and strategies. In UW-Stout, there is a vast range of communication methods used, like websites, newspapers, meetings, visits, and reports. This results in clarification of any doubts, increase satisfaction, and keep people updated with changing environmental conditions.

\section{- Reinforcement}

It was clear that many studies pointed to the importance of reinforcement and motivation from the leadership role (Al-Mashari \& Zairi, 1999; Campbell \& Kleiner, 2001; Peppard and Fitzgerald, 1997). Many studies specifically on - psychological approaches, such as Moran and Brightman (2000) stressed how people's behaviour could change, for example accepting change if their feeling of insecurity is manageable. HEI-A highlighted the importance of these factors, such as praise and a letter of recognition from the management and leader, to make the process - change occur successfully.

The emphasis on monetary rewards was equally important depending on employees' contributions. Zaugg and Thom (2003) claimed that by using an appropriate incentive system that addresses the needs of the employees, one could positively influence them in their decision to remain in the company. This is in line with what - was reported by the participants in all case studies that reinforcement on a monetary basis is as important as on a non-monetary basis. However, in order to ensure value and recognition of employees' contributions, there is a need for more on tangible value, therefore most cases stressed monetary recognition. Interestingly, in HEI-B and HEI-C, monetary reward was obvious, since this organisation operates more on a business orientation, and employees could gain more by being involved more in its activities. Most of the employees agreed that this factor had motivated them to fulfil management direction so as to implement change, because they believed that they would not be neglected and left behind.
Rowley (1996) clearly pointed to the need for leaders to recognise that different motivators are appropriate for different staff in higher education. There is a need for a more balanced approach to give equal opportunity for all employees to get benefits. In addition, Champy (1995) declared greater recognition, in terms of both financial and psychic given to individual and teams who contribute to the success through their innovativeness and support the business requirements, was important. UW-Stout examples of awards/recognition eligible for its staff, were such as 'Outstanding Teaching Awards' for faculty and academic staff, 'Outstanding Service Award' for academic and classified staff, and 'Exceptional Performance Awards' for the faculty.

It should be noted that both monetary (such as salary and bonus) and non-monetary (such as motivation and soft values) reinforcement are equally important, depending on the situation and individual.

\section{Commitment and Support}

Radical process change requires top management commitment and sponsorship as one of the common principles in order to make it a success. It was found that in each case, the participants verbally expressed this factor, however we observed that there are different kinds of approaches to show this commitment and support by them. To be specific, leaders in HEI-A as well as in HEI-C showed their support and commitment to everybody that they should get involved in whatever moves that were made in the organisation by actively giving publicity to these activities. They used communication channels like the intranet website and newsletters.

It is believed that employee motivation would increase and make them together support the radical process change made by the organisation, since they are aware that the leaders also give their commitment and support to these changes, not just paying lip-service. This view is parallel with Harrington (1998) and Vakola, Rezgui, and Wood-Harper (2000), who found that leadership commitment needed to be maintained and enhanced through communication and the people issue was found important in any change effort. This approach was also practised by UW- 
Stout, whose leaders are highly committed to any improvement efforts and make this known in the whole university. Therefore, an effective approach to showing leader commitment is also important in the organisation, together with their actual involvement. This is because without management or leadership support throughout the organisation, any process change effort is doomed to failure, since employees lose their feeling of belonging. Itshould be noted that the most difficult process change to achieve is not with technology, but with people.

- HEI-B stated the importance of leader support and commitment, not only when stating the implementation stage of the process change, but it also should come earlier, at the change initiative stage. This view was comparable with Mumford (1999), whom found that commitment to change from organisational leadership is one of the factors contributing to good organisational design. For that reason, it was proved that leadership commitment and support were important for making process change successful and should be established throughout the organisation to make everybody aware and ready give their commitment as well.

In summary, support and commitment from the leader would enable employees to take the initiative in the problem-solving process, particularly by giving financial support to the process change projects. At the same time, the involvement of the leader in the projects should - also be made known to employees in the organisation, for example through publicity.

\section{Leadership Qualities}

Not many authors work on this issue while approaching the process change efforts. Only a few authors have addressed this, and they only discussed it generally (Davenport, 1993b; Talwar, 1993; Valiris \& Glykas, 1999). However, this paper found that this factor is important, since all of the cases stressed the need for empathic, tolerant, and charismatic leaders to ensure successful process change. This paper believes that it is the leader who should become a role model to influence others to make changes. HEI-A stressed that the leader should lead by example in order to gain respect and develop trust among employees to accept the move and be confident that it would end up successfully. This paper presents these characteristics (for example, being a role model, leading by example, being empathic, tolerant, and charismatic) under one heading: leadership qualities. Most of the HEI-C leaders, for example the CEO, vice president (VP) and deputy VP were perceived to have charisma in terms of appearance and their way of inspiring people to move in the organisational direction. In UW-Stout, the Chancellor meets twice each month with the UW System President and other chancellors, exchanging information and engaging in system-wide planning. Other UW-Stout administrators and governance leaders meet regularly with UW System peers to discuss issues and opportunities to share best practices. As one of the major requirements in MBQNA, quality characteristics of leadership were verified in this university, such as leading by example, and being proactive, responsive, and innovative. Furthermore, UW-Stout (2003) revealed the survey results indicated a high level of satisfaction with its leadership.

Other than those factors highlighted as leadership qualities, we agree with davenport (1993a), who included more factors such as skilfulness, determination, persistence, and patience. The factors like determination and persistence were dominant in HEI-B which were said to exist within HEI-B to aid successful process change projects and meet targets and deadlines. Hence, the leaders were said to have particular qualities, characteristics, and attributes which contributed to the employees making changes and avoid resistance to change. The leaders need to show positive self-values to employees, and the need to take action parallel to their self-values, for example a proactive leader could be viewed as charismatic (Crant \& Bateman, 2000) in order to get employees committed to make change. Leadership qualities assist the organisation to meet targets by making changes acceptable and getting support from employees. 


\section{CONCLUSION}

This paper highlights that strong leadership has been clearly seen as an important and vital requirement for process change to happen successfully, and it has discussed its major factors. We stress that leadership is the foundation to successful implementation of a radical process change. It should be discovered that leadership is a complicated factor in making change, particularly in this research on how it contributes to the success of process change. This research has found significant results on those factors after - performing validation across case PHEIs. The important factor highlighted here is how the leader could influence others in doing what he or she wants. In order to fill the gaps on how the leader could enable process change to happen as intended, the researcher highlights all major - factors revealed in this study to achieve this aim.

\section{REFERENCES}

Ahmad, R. (2003). Cognitive Processing in Performance Appraisal. PhD. Thesis, University of Bradford, Bradford.

Ahmad, R. \& Spicer, D. (2002). A study of the cognitive processing models used in the appraisal system: the Malaysian Public Service. ASIAN Academy of Management Journal, 7(2), 1-16.

Al-Mashari, M. \& Zairi, M. (1999). BPR implementation process: an analysis of key success and failure factors. Journal of Business Process Management, 5(1), 87-112.

Al-Mudimigh, A., Zairi, M., \& Al-Mashari, M. (2001). ERP software implementation an integrative framework. European Journal for Information Systems, 10(4), 216-249.

Altman, Y. \& Iles, P. (1998). Learning, leadership, teams: corporate learning and organisational change. Journal of Management Development, 17(1), 4455.
Applebaum, S. H. \& Wohl, L. (2000). Transformation or change: some prescriptions for health care organizations. Managing Service Quality, 10(5), 279-298.

Ascari, A., Rock, M., \& Dutta, S. (1995). Reengineering and organisational change: lessons from a comparative analysis of company experience. European Management Journal, 13(1), 1-30.

Benito, J. G., Martinez-Lorente, A. R., \& Dale, B. G. (1999). Business process reengineering to total quality management: an examination of the issues. Business Process Management Journal, 5(4), 1463-7154.

Berrington C. L., \& Oblich, R. L. (1995). Translating business reengineering into bottom-line results. Industrial Engineering, 27(1), 24-27.

Burlton, R. T. (2001). Business Process Management: Profiting from Process. Indiana: SAMS Publishing.

Campbell, S. \& Kleiner, B. H. (2001). New developments in re-engineering organisations. Management Research News, 24(3/4), 5-8.

Champy, J. (1995). Reengineering Management: the Mandate for New Leadership. London: Harper Collins Publishers.

Crant, J. M. \& Bateman, T. S. (2000). Charismatic leadership viewed from above: the impact of proactive personality. Journal of Organizational Behavior, 21(1), 6375 .

Dale, M. (1994). "The re-engineering route to business transformation." Journal of Strategic Change. 
Davenport, T. (1993a). Process Innovation: Reengineering Work Through Information Technology. New York: Ernst \& Young.

Davenport, T. (1993b). Need radical innovation and continuous improvement? Integrate process reengineering and TQM. Planning Review, 21(3), 6-12.

Edwards, C., Braganza, A. \& Lambert, R. (2000). Understanding and managing process initiatives: a framework for developing consensus. Knowledge and Process Management, 7(1), 29-36.

Francis, A. \& MacIntosh, R. (1997). The market, technological and industry context of business process re-engineering in the UK. International Journal of Operations and Production Management, 17(4), 344-364.

Grieves, J. (2000). Introductions: the origins of organisational development. Journal of Management Development, 19(5), 345447.

-

Guimaraes, T. (1999). Field testing of the proposed predictors of BPR success in manufacturing firms. Journal of Manufacturing Systems, 18(1), 53-65.

Halachmi, A. (1995). Re-engineering the disability determination process: a case study. Journal of Work Study, 44(8), 21-27.

Hall, G., Rosenthal, J., \& Wade, J. (1993). How to make reengineering really work. Harvard Business Review, 71(6), 119131.

Hammer, M. \& Stanton, S. (1995). The Reengineering Revolution Handbook. London: HarperCollins Publisher Inc.

Harrington, H. J. (1991). Business Process Improvement: the Breakthrough Strategy for Total Quality, Productivity, and Competitiveness. New York: McGrawHill, Inc.
Harrington, H. J. (1998). Performance improvement: the rise and fall of reengineering. The TQM Magazine, 10(2), 69-71.

Hayes, J. (2000). The theory and practice of change management. New York: PALGRAVE.

Homa, P. (1995). Business process re-engineering : theory and evidence-based practice. Journal of Business Process Reengineering \& Management Journal, 1(3), 10-30.

Huber, G. P. \& Glick, W. H. (1995). Organizational Change and Redesign. New York: Oxford University Press, Inc.

Kock, N. F. J. \& McQueen, R. J. (1996). Is reengineering possible in the public sector? A Brazilian case study. Business Change and Re-engineering, 3(3), 3-12.

Kotnour, T. (2001). Building knowledge for and about large-scale organizational transformations. International Journal of Operations \& Production Management, 21(8), 1053-1075.

Kotter, J. P. (1995). Leading change: why transformation efforts fail. Harvard Business Review, 73(2), 59-67.

Laiken, M. E. (2003). Models of organizational learning: paradoxes and best practices in the post industrial workplace. Organizational Development Journal, 21(1), 8-19.

LaMarsh, J. (1997). The resilient worker: employees who can cope with change. Hospital Material Management Quarterly, 19(2), 54-58.

Mabin, V. J. Forgeson, S., \& Green, L. (2001). Harnessing resistance: using the theory of constraints to assist change management. Journal of European Industrial Training, 25(2/3/4), 168-191. 
MacIntosh, R. \& MacLean, D. (1999). Conditioned emergence: a dissipative structures approach to transformation. Strategic Management Journal, 20(4), 297-316.

Markus, M. L. \& Benjamin, R. I. (1997). The magic bullet theory in IT-enabled transformation. Sloan Management Review, Winter, 55-68.

McAdam, R. (2003). Radical change: a conceptual model for research agendas. Leadership \& Organization Development Journal, 24(4), 226-235.

Miles, M. B. \& Huberman, A. M. (1994). Qualitative Data Analysis. California: SAGE Publications.

- Moran, J. W. \& Brightman, B. K. (2000). Leading organizational change. Journal of Workplace Learning, 12(2), 66-74.

Mumford, E. (1999). Routinisation, Reengineering, and Socio-technical Design: Changing Ideas on the Organisation of Work. In W. L. Currie \& B. Galliers (Eds.), Rethinking Management Information Systems: An Interdisciplinary Perspective. New York: Oxford University Press.

Peppard, J. \& Fitzgerald, D. (1997). The transfer of culturally-grounded management techniques: the case of business process reengineering in Germany. European Management Journal, 15(4), 446-460.

Pritchard, J.-P., \& Armistead, C. (1999). Business process management - lessons from European business. Business Process Management Journal, 5(1), 10-32.

Rowley, J. (1996). Motivation and academic staff in higher education. Quality Assurance in Education, 4(3), 11-16.
Smith, M. (2003). Business process design: correlates of success and failure. The Quality Management Journal, 10(2), 3849.

Talwar, R. (1993). Business re-engineering - a strategy-driven approach. Long Range Planning, 26(6), 22-40.

Tinnila, M. (1995). Strategic perspective to business process redesign. Management Decision, 33(3), 25-34.

UW-Stout. (2003). 2001 Malcolm Baldrige National Quality Program Application: The School of Choice for 21st Century. Retrieved June 13 2003, from http://

Vakola, M. Rezgui, Y., \& Wood-Harper, T. (2000). The Condor business process reengineering model. Managerial Auditing Journal, 15(1/2), 42-46.

Valiris, G. \& Glykas, M. (1999). Critical review of existing BPR methodologies: The need for a holistic approach. Business Process Management Journal, 5(1), 6586.

Yin, R. K. (1994). Case Study Research: Design and Methods. London: SAGE.

Zairi, M. (1999). The learning organisation: results of a benchmarking study. The Learning Organisation, 6(2), 76-81.

Zaugg, R. J. \& Thom, N. (2003). Excellence through implicit competencies: Human resource management - organisational development - knowledge creation. Journal of Change Management, 3(3), 199-211. 